\title{
Indiana University Libraries, 1829-1942
}

\author{
BY MILDRED HAWKSWORTH LOWELL
}

$\mathrm{D}$ ID THE LIBRARIES at Indiana University develop according to a plan which recognized the changing role of the academic library in higher education? Did the people of Indiana University consciously seek to remodel the libraries to meet changing needs? Did they have a well-conceived and unified plan for the development of library services? Or did the library developments, although attached to the growth of the university, result from the needs and contingencies of the moment and the pressures generated in the changing university? These questions can be answered in terms of (1) what people said about the library, its scope, etc. and (2) what actually happened in the library.

Why did the Hoosier pioneers want a university with a library? The majority of early settlers in Indiana were poor, hard-working, southern farm people who were attracted to Indiana because of the liberal land policy. These were the people who dominated the educational objectives and philosophies of the state and in 1807 passed an act of the Territorial Legislature to incorporate a university and to finance a university library. The Hoosiers wanted a university in which capable youths regardless of their economic status could be educated for intellectual leadership. They believed in individual freedom and the worth of the plain people and envisioned a tax-supported system of education ascending in regular gradation from primary schools to a university. The university with its library was the ultimate goal in the educational development of the individual.
Mrs. Lowell is Lecturer, Division of Library Science, Indiana University. This article is a condensation of the author's Ph.D. dissertation at the Graduate Library School, University of Chicago, December, 1957.

\section{The Board of Trustees Develops} THE LiBRARY, 1829-1874

Indiana University had its origin in a legislative grant in 1820. Two buildings were erected and the first classes in Greek and Latin were started in 1824. This was the only institution of higher education in Indiana at that time and was one of four on the western frontier. A room was provided in the first building for a library, and the trustees directed the first president to select the original collection which he brought to Bloomington when he assumed the presidency in 1829. This collection of books and the private libraries of the faculty members were the students' only sources for printed materials. Although there was some publishing clone in the state at this time (newspapers; religious, legal, and literary books; and printed political speeches and broadsides), it was not relevant to the college curriculum. Because of the lack of transportation facilities, it was difficult to obtain publications from the east. The first east-west and north-south roads in the state were started in 1830. Indian tribes were still a subject of grave concern. The only other libraries in the state were private ones at Vincennes and New Harmony, and the Indiana State Library at Indianapolis, for which the first volumes came by stagecoach in 1824 .

At a meeting of the board of trustees in 1837 , library rules were adopted, and 
William R. Harding, tutor of the preparatory department, was appointed librarian for the academic year; he was followed by James Findlay Dodds in 1838. Theophilus A. Wylie became librarian in 1841 and served until 1879 . All three librarians carried a full teaching load. Reports of the board of trustees frequently referred to the library and its development, indicating both pride and interest on the part of the members. This pride was justified when one realizes the condition of pioneer life at this time. The book collection grew slowly by means of occasional appropriations from the board, gifts of documents from the state and federal governments, and a few gifts from individuals.

During the period 1829 to 1874 , the library was open on Saturday mornings for the circulation of books; this was typical of academic libraries in the nation at that time. Non-curricular use of the library was made both by faculty members and by students, but no reading room was provided. The board directed in 1842 that a catalog listing the contents of the library be compiled and printed. Catalogs for several academic libraries had been printed prior to this time. A study of the holdings of Indiana University Library as listed in the 1842 catalog revealed an unusually fine collection which had been specifically selected for the needs of the curriculum as well as for informational and cultural reading. Many lexicons, dictionaries, concordances, etc., were available for use in the curriculum. Trustees provided the library with current historical and literary works which they believed should be available for students and members of the faculty.

This library of about five thousand volumes, the law library, and the two literary society libraries were destroyed by fire April 9, 1854. The university library collection represented about 22 per cent of the more valuable book resources of the state and was a great loss not only to the university but also to the cultural development of the state, which was just emerging from the pioneer era at this time.

A new building was erected after the fire, and two rooms were assigned to library use-one for the university library and one for the law library. The curriculum had expanded to two coursesthe four-year "regular course" of classical studies leading to the Bachelor of Arts degree and the three-year "scientific course" leading to the Bachelor of Science degree. The new university library received a good start in 1855 when a bookseller and publisher of Cincinnati offered the university $\$ 1500$ worth of books from his stock to be selected by the faculty, and the board of trustees appropriated a large sum of money. After the student newspaper started publication in 1867 , students made their library needs known. They recognized the need for a reading room in the library furnished with newspapers and periodicals to be used by all students for recreational reading and by debaters in finding material for their speeches. A new era began for the library in 1875 with the inauguration of a president who believed in libraries, a regular annual library budget, and provision of larger quarters specifically planned for library use.

\section{Four Presidents Influence \\ LIBRARY GROWTH, 1875-1904}

The library's development from 1875 to 1904 was influenced directly by presidents Moss, Jordan, Coulter, and Swain. The board of trustees continued to make certain decisions relative to the library, but it never again controlled the library as it had prior to the appointment of Dr. Moss in 1875. The thinking of these presidents was influenced to some extent by ideas acquired at professional meetings and through professional literature. National developments in communication and transportation during the last quarter of the nineteenth century broke down the isolation of professional peo- 
ple, and scholarly and scientific activity began to center in the colleges and universities. This new intellectual activity, plus several library and publishing developments, in turn affected the development of all libraries in the nation.

Moss's philosophy regarding the place of the library in the curriculum marked the beginning of a wider, more educationally effective type of library service. He built up the natural and liberal arts, outlined programs leading to the master's and doctor's degrees, and introduced history and elective subjects into the curriculum. These curricular changes created new demands upon the library.

Moss was responsible for obtaining an annual budget for the library, for opening the library every day, and for appointing a full-time librarian, William Wesley Spangler, who held this position from 1880-1893. Spangler opened a reading room where magazines, newspapers, and books were available, and during his regime the library was designated as a depository for all public documents published in the state of Indiana and by the U. S. government. Only six years after Dewey's decimal classification was published and when the making of card catalogs was not common, Spangler classified the books according to Dewey and prepared a card catalog of the collection. He also offered library instruction. This library of twelve thousand volumes and three thousand pamphlets was destroyed by fire on July 12, 1883 .

Because the campus was too small for the growing university, the board of trustees decided after the fire to acquire a larger site. Provision for the library was made in Wylie Hall, one of the two buildings erected on the new campus. A year and a half after the fire, David Starr Jordan succeeded Moss as president, and on his second day in office asked the alumni to persuade the legislature to appropriate money for replacing the librarv. The resulting appropriation was the largest received by the library up to that time, and it was not equaled or exceeded until 1879. Jordan made his personal collection of reference books accessible to biology students, introduced the major subject system into the curriculum, and encouraged promising alumni to study abroad and prepare for teaching at Indiana University. When these men returned, they brought seminar teaching methods to the campus and started laboratory collections of books which later became departmental libraries. New library rules adopted in 1887 gave the librarian more authority in managing the library, and authorized the president to decide on the use of books by departments.

As the new book collection was acquired, it was classified by Dewey decimal classification, cataloged in a dictionary card catalog, and made available on open shelves. By June 1888 the librarian's responsibilities had increased so greatly that it was necessary to employ three catalogers to assist Librarian Spangler. The librarian lectured to classes about library classification and to groups of new students about the library and its use. At about this time library instruction similar to that offered by Spangler was being given at Amherst, Bowdoin, Colgate, California, Cornell, Wellesley, Iowa State Agricultural College, Johns Hopkins, and Michigan.

The rapidly growing book collection and the reestablishment of the law school and its library in 1889 created pressure for a separate library building. Maxwell Hall, completed in 1891, was designed to house the main university library, the law library, and some teaching departments. Because there was extensive development in university library building at this time in the United States, this building benefited from professional library opinion, from improved building techniques, and from architectural thought, which was increasingly emphasizing functionalism in planning. The provision of a reference reading 
room in the building reflected the acceptance at this time of the theory of reference service by American libraries generally.

John Merle Coulter, a botanist, who served as president from 1891 to 1893 , carried forward Jordan's educational and scientific ideas, including the encouraging of research, and, in addition, offered extension classes to the people of the state. Departmental libraries for botany, zoology, and mathematics were announced in 1891, and within a few years departmental libraries also existed for geology, chemistry, and physics.

Dr. Joseph Swain, who succeeded Coulter as president in 1893, called attention in his inaugural address to the necessity for increasing library facilities. Throughout his nine years as president, he was keenly interested in the development of the library and chose the librarians with great care. Swain considered it highly important that the library be as useful as possible to students and professors and believed it was necessary for a librarian to be trained for the work. Some other colleges and universities at this time were beginning to employ professionally trained librarians. While searching for a librarian to replace Spangler, he appointed Louise Maxwell as acting librarian from 1893 to 1896. She found it necessary to change Spangler's open-shelf policy because of damage to the books, separated the stacks from the reading room, and instituted a system of stack permits. Alexis V. Babine, librarian from 1896 to 1898 , brought to his position a knowledge of book discounts and ordering practices used by other libraries. $\mathrm{He}$ limited the circulation of books because he wished the collection to be available in the library at all times, employed student assistants, and created another reading room. During his term as librarian, from 1898 to 1903, George Falvel Danforth instituted a reserve book system, provided a faculty reading room, and the library hours were lengthened. Danforth devised a new classification scheme, and the book collection was reclassified and recataloged. He taught the first summer library course offered in Indiana, and edited two ambitious bibliographical works, one of which was the United States Catalog; books in print, 1899.

Each of the four presidents from 1875 to 1904 worked diligently to increase the library appropriations, and as a result library expenditures in 1903 were almost 2000 per cent greater than in 1875 . By the end of this period, the administrative organization had become so complex, the president was able to give less and less time to the details of library management, and a strong library administrator became necessary. Simultaneously, during these years the librarian had gradually become increasingly important in guiding the library's development, and during the first quarter of the twentieth century, Jenkins, appointed in 1904, dominated library management and control.

The Jenkins Administration, 1904-1921

The administration of William Evans Jenkins, from 1904 to 1921 , reflected the new profession of librarianship which had been evolving nationally and the growing body of knowledge in library science. He had studied at the New York State Library School, had a wide knowledge of books and understood their worth and use in instruction and research. He had a grasp of established principles of library management and at the same time was capable of working out innovations to meet changing conditions. During his administration, he established policies in regard to purchasing, cataloging, building, use, library science courses, reference service, and classification which were sound and offered solutions for current problems as well as objectives for the future.

Greater continuity and better planned development of the library were possible during Jenkins' administration because 
the same librarian and the same president served during these years. William Lowe Bryan took office as president August 1,1902 . He recognized the needs of the state and believed the university should provide professional and graduate training. As a result, the university curriculum was expanded greatly with the addition of new courses, departments, and schools. From 1904 to 1921, the enrollment increased more than two and one-half times, the library staff doubled, and the number of volumes in the library and the circulation almost tripled.

Many problems in library administration resulted from the practice of giving the instructional departments autonomy over their own book budgets. Jenkins analyzed these problems and offered solutions which were not accepted, but he did make some fundamental changes in the methods of purchasing books and in the handling of departmental balances. By utilizing printed Library of Congress cards (available three years earlier), cataloging was speeded up and done in more detail; the card catalog was essentially remade between 1904 and 1908 . He visited many libraries and examined the building plans of many others in working out the design for a new library building which was ready for occupancy in December 1907. The library rules which limited circulation of books to overnight did not meet with his approval, as he believed a library existed to be used. Upon investigating the policies of other universities, he found no important university library restricted circulation as did Indiana, and more liberal home use rules were put in force in October 1906.

Jenkins organized and taught the first credit course in library science to be offered at Indiana; he outlined a course leading to the degree of A.B. in library science; and he offered a five-hour course in library apprenticeship for the training of library assistants. He employed the first professional reference librarian and offered reference service to the public libraries of the state. Jenkins was the first librarian to become a member of the faculty library committee, and because of his influence, the committee of 1912-13 studied the library needs of the university in detail and compared the library with those of other universities. As a result of this study, the financial status of the library was greatly improved in the following years.

Although the disadvantages of the Danforth classification system had been felt for many years, Jenkins hesitated to reclassify because of insufficient staff, lack of agreement among libraries as to the ideal classification, and cost. After the United States entered World War I, the library staff was less busy because the book budget and enrollment were lower; it was necessary to replace the classifier who had done all the classifying since the Danforth scheme had been adopted; and eight college or university libraries were utilizing the Library of Congress classification and found it satisfactory. The time seemed right for reclassification. Due to the energy and efficiency of Ida Wolf, the reclassification project was made so unobtrusively as to be almost unnoticed by the users of the library and the cost was negligible.

\section{Faster Growth, Alexander,} ANd the Library CommitTeE, 1921-1942

The library expended at a much faster pace between 1921 and 1942, when William Albert Alexander was librarian, than it had during any previous period. The acceleration in acquisitions grew out of national developments in scholarship and research, which in turn affected developments at Indiana University. These advances resulted from the cooperation of American professional organizations, the wealth that flowed into the universities and other research centers, the dislocations in Europe which interfered with the intellectual pursuits of their scholars, and the improved dissemi- 
nation of the findings of scholarship. American librarians participated in developing tools useful in research projects such as bibliographies, catalogs, finding lists, dictionaries, encyclopedias, microfilm, and microprint. The Association of Research Libraries was organized for the purpose of developing and increasing the resources and usefulness of research collections. Indiana University Library was a member of this organization and staff members produced a Union List of Serials in Indiana Libraries.

Many changes in Indiana University stemmed from or were related to the national advances in knowledge and research. These included changes in curriculum, increased enrollment, the educational philosophy and objectives of President Wells, the work of the most active library committee in the history of the library, and the recommendations of three library surveys. The curriculum was expanded to include new subjects and to meet new demands of scholarship; four new schools were added, and there were many changes in the College of Arts and Sciences. University enrollment almost doubled in the twenty-one years. As the number of students, schools, courses, and the pressures for more adequate research materials increased, the need for better library facilities and services became evident.

A study of the university library was included in Report of a Survey of the State Institutions of Higher Learning in Indiana made in 1926. The surveyors recommended that the book collection be materially strengthened by accelerating the rate of acquisitions and that more staff be employed to take care of the additions. The 1927 legislature appropriated $\$ 50,000$ for each year of the next biennium for the library, and four additional staff members were employed.

Herman B. Wells, who succeeded Dr. Bryan as president in June 1937, believed that, in addition to providing superior education to undergraduates, the univer- sity's research program should be expanded, the influence of the university should reach out to all parts of the state, and the people of the state should be drawn to the campus for educational experiences. To implement the expanded research program, the library committee, between 1937 and 1942, was given the responsibility by the board of trustees to (1) spend wisely a special library fund appropriated for each of these five years, and (2) consider all problems of library administration. The purposes of the fund were to purchase basic books and journals for research and graduate study which involved greater expenditures of money than ordinary departmental book budgets would provide; book collections for new departments and for departments whose library resources were inadequate; and special collections which came on the market and were needed for a department's research program. During the last year of the fund, the library committee was given the responsibility of allotting all book funds to departments as well as the special library fund.

Between 1938 and 1942 the library was surveyed by three groups of people. All departments of the university, including the library, were surveyed in 1938 by a faculty committee. The following year, the ALA board of education for librarianship surveyed the state to ascertain whether or not there existed in Indiana a need for a school which would train librarians for all types of libraries. The Indiana University Library was included in this survey to determine its suitability for use by a library school on the campus. Late in 1939 President Wells and the trustees asked the American Library Association to make a survey of the library.

As a result of these surveys, all libraries on the campuses, both in Bloomington and in Indianapolis, were integrated into a unified system under a director of libraries, all university money appropriated for purchase of library books was to 
be allocated by the director, the library budget was increased, and library instruction was offered during the academic year and eventually became the division of library science. Dr. Robert A. Miller accepted the appointment as director of libraries and assumed his position March 1, 1942. Mr. Alexander continued as librarian until his death July 8, 1943.

\section{Development of Branch Libraries}

Collections of books designed to serve the needs of a specific group of faculty members and students have been called by various names at Indiana Universityseminar, departmental, laboratory collection, and branch library. Some of these collections and reading rooms were shortlived, others persisted through the years and survived to the present. The seminars were located in rooms in the central library set aside for that purpose; the departmental and branch libraries and departmental collections were usually located in another building.

The pattern of development of branch libraries at Indiana University followed in general that for other American universities. The oldest branch library at Indiana was that for law, which existed in 1847. An 1850 report listed branch libraries in universities for law, medicine, and theology. After the seminar method of instructions was introduced from Germany in the 1870 's, departmental libraries in other subjects were established in many American universities. Indiana University faculty members who had used these libraries abroad found them useful and desired the same type of collection on the campus. Libraries for zoology, botany, and mathematics were in existence in 1891-92, a geology library existed in 1894, one for chemistry in 1895, and physics in 1902.

From the time the library moved into its first building (Maxwell Hall) in 1891, there has been a faculty library committee. This committee from 1891 to 1932 was predominantly composed of faculty members in the humanities and social sciences. Probably representation of the sciences on the committee was not considered essential since each science had its own departmental collection. In many large library systems, most of the humanities and some of the social sciences have remained in the general library building.

The School of Medicine Library in Indianapolis came into existence when the school was founded in 1908. Departmental libraries in anatomy, physiology, and astronomy existed in 1913. The School of Dentistry Library in Indianapolis was organized in 1927 just two years after Indiana University purchased the school. The Indianapolis Extension Center Library and the Music Library in Bloomington were organized about this same time. The Business and Economics Library was started in 1937, University School Library in 1938, and Fine Arts Library about 1940.

By the late 1920's, there was a trend in American university libraries away from small and relatively inaccessible collections towards larger and readily available collections. With the change in the 1930's from narrow departmental courses to broader divisional courses and the concept of general education, some university libraries achieved a greater centralization of book resources by combining or eliminating departmental libraries and bringing all branch libraries into a unified system under the supervision of the university librarian.

At Indiana between 1937 and 1940 ten departmental libraries were combined to form four stronger branch libraries; and in 1942 all branch libraries were brought under the control of a director of libraries. Indiana University in 1942 had thirteen branch libraries of varying sizes with wide differences in housing and personnel; ten of these were on the Bloomington campus-Biology, Business and Economics, Chemistry-Bacteriology, Fine Arts, Geology and Geog-

(Continued on page 462) 


\section{Indiana University Libraries}

(Continued from page 429)

raphy, Law School, Medical, Music, Swain Hall, and University School; and three in Indianapolis-School of Medicine, School of Dentistry, and Extension Division. These libraries originated in one of three ways: (I) as a planned separate collection and reading room, (2) as a laboratory collection to serve a science; or (3) as a collection in the office of a dean or departmental chairman.

\section{Conclusions}

The question was posed at the beginning of this study as to whether the libraries at Indiana University developed according to a plan which recognized the changing role of the library in higher education or whether the development resulted from the working of pressures generated in the changing university. The facts would seem to show that the libraries were changing in the direction of a university library but not according to an idea deliberately conceived and carried into effect.

The library in the frontier university reflected a respect for books as instruments of general culture and had only a tenuous connection with the curriculum and program of instruction. The board of trustees, representing the pressures of the general public for more "practical" collegiate education, selected titles of contemporary works in literature, travel, biography, and history which they believed should be read by students. Faculty members seem to have selected titles which had closer relevance to the curriculum and which represented the classical-education point of view. Considerable dependence on the private collections of faculty members for curricular use was evident until late in the nineteenth century; apparently the library did not adequately meet the needs of the instructional program, and it probably was not expected to. In fact, the lack of pressure on the part of faculty members for the acquisition of these materials in the university library may reflect their philosophy about the relation of the library to instruction.

Nine years before the university library provided a reading room, students recognized the advantages of a place where newspapers and periodicals were available as well as books. The rooms of the student literary societies served in a limited way as reading quarters, and their libraries had current newspapers that were used to prepare debates several years before the university library itself subscribed to newspapers.

The growing importance of the library to the university in the last quarter of the nineteenth century is evident from the institution of regular appropriations, the employment of experienced librarians, the concern with buildings and reading rooms, the longer hours of opening, the instruction in library use, and the expressions of interest from both officers of instruction and students. The development of graduate studies and research and the institution of the elective system were significantly parallel with the increasing emphasis on library service during the last quarter of the nineteenth century. As the departments of instruction multiplied, library services grew by accretion rather than by plan. There was ample room in Maxwell Hall when it was built in 1891 to house the small collections of books in the various science laboratories, but the collections were allowed to remain in the departments and develop into departmental libraries. Unfortunately for the university as a whole, there was no plan for the 
development of either the central library or the departmental libraries. In general, the sciences and schools developed separate libraries while most of the social science and humanities collections remained in the central library. The rigid allocation of book funds to departments under departmental supervision contributed to the creation of separate small collections. Departmental libraries continued to develop in a haphazard fashion with no centralized control until 1942, depending upon the professional associations for standards of collection and services rather than integrating their development with the needs of the university as a whole. During the years these departmental libraries were evolving, there is no evidence that the university librarians directed or planned for their growth and integration.

Throughout the history of the library, up to 1942, the librarians of the central library acted chiefly as housekeepers rather than as officers of instruction and were concerned with classification schemes, cataloging, rules and regulations, housing, personnel, etc. Some librarians were aware of general library development and utilized ideas gained from observing practices in other libraries to improve the internal organization of the central library. The activities of the library staff at the level of teaching and research were rather limited prior to 1942; some library instruction was offered, several guides to the libraries were printed, exhibits and displays designed to stimulate reading were arranged, and some bibliographical projects were done. The members of the library staff participated in the activities of professional library organizations and served on campus committees.

The most instrumental personal agents in the library development were the major officers of instruction in the university. The presidents, especially those after 1875, obtained appropriations from the general assembly, argued the library's cause before the board of trustees, searched widely and diligently to find well-qualified persons to fill the position of librarian, recommended titles and areas in which acquisitions were desirable, cooperated with the librarian in disciplining students, helped the board of trustees and/or librarians to make library rules and regulations, and appointed faculty members to serve on the library committee. The deans and department heads were active in outlining acquisition programs and selecting titles for departmental collections, in serving on the library committee, in promoting the acquisition of research materials in the central library, and in developing branch libraries.

Some faculty members seem to have been aware of the changing role of the academic library and they consciously sought, through the development of departmental libraries, to remodel library service to meet changing needs. The departmental libraries resulted from the desire of some faculty members that books be near classrooms and/or laboratories for easier access and so that closer supervision of both students and books could be exercised. Some faculty members gave generously of their time over a period of years to build up collections in their subject fields. Both faculty members and librarians were active in utilizing campus publications as exchanges for other publications.

Although attached to the growth of the university, Indiana University $\mathrm{Li}$ braries developed chiefly as the result of the needs and contingencies of the moment. Pressures were generated in the changing university by individuals (members of the board of trustees, the presidents, members of the faculty, and students); by fashions and trends in library development; by surveys of the library; by the addition of graduate study and research to the university program; and by changes in teaching method and in curriculums. 
The findings of this study, which show the library to be affected by the various pressures in the university, really indicate it to be a secondary growth of the university. Such a secondary growth, in spite of the best and most enlightened attempts to plan library development, is almost certain to respond to whatever twists the university development takes. This growth could be unified and logical only if university developments were characteristically unified and logical.
When the growth of the university itself is in response to external pressures and stresses, as it often was at Indiana, the library is compelled to develop in a somewhat similar manner. Although Indiana University Libraries in 1942 were under the direction of a new administration with a firmer and better planned control, it is likely that irrational forces will continue to help shape the library insofar as the development of the university itself is subject to such forces.

\section{Bibliomania}

reprinted with permission of

Emory University Quarterly

I like the looks

Of books.

I like to cast my eyes along the rows

Of stately folios

Or, ranged on neighboring shelves,

Quartos and dumpy twelves.

I love the multicolored bindings, whether

Cloth, buckram, or leather.

I like the smells of papers, pastes, and inks,

Spiced like a bed of pinks.

A book in weight and format subtly planned

Is comfort to the hand.

And there's no hue more pleasing to the sight

Than black on white.

A page of Caslon or of Baskerville,

Or rarer still,

Broad Gothic letter firmly set

And inked like jet,

With fair-proportioned margins rising high,

Delights the eye.

There is no limit to a book's appeal;

Its looks, its feel,

Give me such pleasure that I scarcely need

To read.

- Thomas H. English 